\title{
PROMOTIONAL STRATEGY ANALYSIS IN IMPROVING THE ROOMS IN ZODIAK HOTEL KEBON KAWUNG
}

\author{
Taufansyah Firdaus \\ taufansyah.firdaus@stiepar.ac.id \\ Indah Nur Agustiani \\ I Made Dwipa Agastya \\ STIEPAR YAPARI-AKTRIPA Bandung, Indonesia \\ Jl. Prof. Dr. Sutami No.81-83, Sukarasa, \\ Sukasari, Kota Bandung, Jawa Barat 40163
}

received: 21/6/18; revised: 19/11/18; published: 31/12/18

\begin{abstract}
This research aims to analyze the appropriate promotional strategies in increasing the occupancy of the Zodiak Kebon Kawung Hotel Bandung. 15 respondents were taken as a sample of research using purposive sampling from employees of executive sales and executive e-commerce at Zodiak Kebon Kawung Hotel. The analysis used is a SWOT analysis consisting of internal factor analysis factor (IFAS) matrix, external factor analysis summary (EFAS) matrix, external-internal matrix (IE), cartesian diagram and SWOT matrix. These are the position of growth strategy with IFAS score $=2.21, E F A S=2.50$, dan SWOT Matrix; 1) SO strategy ie accessibility of adequate means of transportation, modern hotels; 2) ST strategy that is not expensive and supported by security; 3) WO Strategy that is to improve human resources, facilities and infrastructure of water and sewage treatment, improvement of in-room facilities; 4) WT strategy is to avoid the transfer of educated and experienced personnel.
\end{abstract}

Keywords: promotion strategy; SWOT analysis; SWOT matrix

\section{INTRODUCTION}

The high influence of the tourism industry on foreign exchange earnings of the country makes it as one of the sectors to consider its development. Based on data obtained from the branding Wonderful, the competitiveness of Indonesian tourism experienced a sharp jump from 2013 to 2017, which is from the 70th to the 42nd (Liputan6.com (Ibo,2018)). This is also in line with the increasing number of foreign and domestic tourists who visit Bandung to enjoy the various destinations and attractions that are available.

The rapid development of tourism activities in Bandung, utilized by entrepreneurs and stakeholders to invest funds in the development of accommodation services, in the form of development of hotels with various levels and facilities. For example, Zodiak Kebon Kawung Hotel is one of the budget hotels located at Jalan Kebon Kawung No.54 Pasir Kaliki Cicendo Bandung, managed by Kagum Group and operated since 2011. This hotel has 2 type of room, function, meeting room, ballroom, restaurant, and room facilities that sufficient with budget hotel type. This hotel also has many similar competitors that are located not far from the hotel.

The hotel's ranking position (Table 1) is determined based on reviews provided by guests who have dropped in to stay in accordance with the service, cleanliness, timeliness of check-in and special requests by room bookers at each hotel through Tripadvisor.com. This may affect the rating of the hotel so that every hotel should make improvements to the system, improvement of services, food and beverage products, hygiene, security, and promotions provided to increase the occupancy rate of rooms in these hotels.

Hotel Zodiak Kebon Kawung continues to conduct annual evaluations to continue to improve the promotion and service quality in order to improve room occupancy and not be left behind by other hotel competitors. However, until now the occupancy rate of the targeted Zodiak Kebon Kawung Hotel has not reached the target despite making some efforts in the promotion strategy (Table 2).

Room occupancy rates in the last four years, namely from 2011 to 2015, decreased presentation (Table 2). The problem that caused the decline is the possibility of many 
competitors. This is seen based on the growing number of hotels with various types of hospitality concepts. The problems faced by the hotel must have a better promotion strategy so that customers always use hotel products (services). As expressed by (Chandra, S. M., \& Tielung, M. V., 2015) that hotel management in achieving residential targets, must have a strategy to increase attractive promotional efforts. Because, the promotion has an important role in contributing to increasing hotel room occupancy (Anderson, C. K. 2012).

The main goal in conducting promotions is to increase the occupancy space that is consumers and satisfaction. As stated by (Mandasari, K., \& Soesanto, H. (2011) which states that the most important goal of the strategy is consumers' satisfaction, conditions that must meet consumer expectations. increasing the hotel room occupancy are the distance from the city center, hotel size, and hotel price level in increasing the hotel room occupancy. general in the city where the hotel is located (Radojevic, T., Stanisic, N., \& Stanic, N., 2015).

The company's goal in increasing room occupancy is to maintain survival, develop and earn profits. The efforts made besides increasing promotion also increase competitive advantage, in this case, are cost and differentiation. Molina-Azorín, et al., 2015 shows that quality management and hotel environments can enable competitive advantage in terms of cost and differentiation.

Cost is one of the important factors in a company to make a profit. Every business actor tries to set affordable prices for their competitors. Many companies go bankrupt because they set prices that don't match the market. The price set must be in accordance with the consumer economy so that consumers can buy goods and services (Gulla, R., Oroh, S. G., \& Roring, F., 2015). In addition, hotel management must pay attention to the best service, because it will have an impact on the customer's attitude towards the hotel and can spread online (Zervas, G., Proserpio, D., \& Byers, J. W., 2017).

Kebon Kawung Zodiac Hotel has both promotional and online designs. This shows that the Kebon Kawung Zodiac Hotel has a promotional strategy to increase room occupancy. However, the target room occupancy guests have not been reached (Table 2). Therefore, indepth search and analysis of marketing strategies are needed at the Zodiac Kebon Kawung Hotel to increase room occupancy using SWOT analysis.

\section{METHODS}

Research Design. This research was conducted to analyze the promotion strategy used by Zodiak Kebon Kawung Hotel using SWOT analysis. The instrument used in this study is a questionnaire filled by employees of executive sales and executive e-commerce related to the promotion strategy of Zodiak Kebon Kawung Hotel. Furthermore, the data obtained from the questionnaire is recapitulated and tabulated to obtain a basis in determining the promotion strategy in increasing the occupancy of Zodiak Kebon Kawung hotel room.

Target research. This research uses purposive sampling as a method in determining the sample research so that it can be concentrated on the subject of research (Etikan, Musa \& Alkassim., 2016). The determination of sample selection is based on the research needs of respondents who understand about the state of the hotel, both internally and externally, so that the number of respondents used in this study is 15 people.

Data collection technique. The questionnaire used consisted of 10 indicators in internal indicators and 10 external indicators. Questionnaires were supplied by respondents to give weight and rating. Data collection technique. The questionnaire used consisted of 10 indicators in internal indicators and 10 external indicators. Questionnaires were supplied by respondents to give weight and rating. Determining the performance score of an object is by way of judgment (judgment value). The score of positive factor, the score given starting from SL (very weak) $=1, \mathrm{~L}$ (weak) $=$ $2, \mathrm{~K}$ (strong) $=3$, SK (very strong) $=4$, and for the negative penalty factor threat) The scale of the negative penalty factor, the score given from SK (very strong) $=1, \mathrm{~K}($ strong $)=2, \mathrm{~L}($ weak $)=3, \mathrm{SL}($ very weak $)=4$ (Brahmanto, Hermawan, \& Hamzah , 2017). Weight assessment of promotional strategy can be seen from the total value of the maximum weight. This is to facilitate the scoring and weighting in the internal factors analysis summary (IFAS) table and external factors analysis summary (EFAS).

Data analysis used were internal factors analysis factor matrix (IFAS), matrix of external factor analysis summary (EFAS), and SWOT matrix. SWOT analysis is used to look at the factors that are the strength of the object (strengs), weakness of the object (weakness), opportunities of development (opportunities) and possible external factors that threat (treatments) (Rangkuti, F., 2011); (Brahmanto, Hermawan, \& Hamzah, 2017), (Wijaya, Priyono, \& Santoso, 2018)) in promotion strategy in the improvement of room occupancy in Hotel Zodiak Kebon Kawung.

Data analysis used next is to use a type of quadrant strategy consisting of four possible strategies, namely strength and opportunity and simultaneously can minimize the weakness and threat ((Rangkuti, F., 2011); (Wijaya, Priyono, \& Santoso, 2018)). It is expected to be able to balance between internal conditions, namely: strengths and weaknesses with external conditions in opportunities and threats that are then implemented in the SWOT matrix to get the best strategy. The positioning in the Internal-External (IE) matrix is as follows: 


\section{RESULTS}

The calculation uses the SWOT matrix (Table 3) internal factors analysis summary that the power insternal factor has a total of 1.37 of the weighted product, the insider's internal factor rating has a total of 0.84 , from the weighted and rating results, if the strength factor set aside by the weakness factor will result the weight of 0.53 on the axis of strength is based on the requirements applicable to the SWOT analysis theory of external factors analysis summary. Total value of IFAS $=2.21$. This indicates that the position of Hotel Zodiak Kebon Kawung at the stage of growth and has medium.

The calculation uses a SWOT matrix of external factors analysis summary (Table 4) that the external factor of opportunity has a total of 1.67 of the weighted and rating multiplications while the external threat factor has a total of 0.83 of the weighted and rating results, if the probability factor is set aside by the threat factor will result weights 0.84 on the axis of opportunity, this is based on the requirements applicable to SWOT theory analysis of external factors analysis summary. Total value of EFAS $=2.50$. This indicates that the position of Hotel Zodiak Kebon Kawung at the stage of growth and has medium.

Based on data of internal factor analysis factor matrix (Table 3) and matrix of external factors analysis summary (Table 4) it can be concluded that Zodiak Kebon Kawung hotel position is in quadrant $\mathrm{V}$ that is growth strategy. Quadrant V diagram can be seen in Figure 2.

Based on Figure 1 in the Cartesian diagram can be deduced by looking at the reduction of internal factors; strengths, weaknesses, and external factors; the threat possibility of producing the first quadrant is the growth with the final weight of the axis of opportunity is at 0.84 , and the axis of strength is at 0.53 .

SWOT analysis is used to see the factors that become the strength of the object of strengths, weakness, opportunities and the possibility of external factors becoming treats in promotion strategy in increasing occupancy room at Hotel Zodiak Kebon Kawung (Figure 4).

\section{DISCUSSION}

Based on the analysis of internal factors analysis matrix analysis (Table 3), matrix of external factors analysis summary (Table 4), external-internal matrix (Figure 2) and cartesian diagram (Figure 3), it is found that the main strategy of Zodiak Kebon Kawung hotel is growth strategy where the hotel Zodiak Kebon Kawung can develop its hotel by developing facilities and utilizing a better promotion that is by paying attention to the effect on the price of several characteristics associated with different locations for each type of accommodation.
This is in line with the results of research which reveal that the findings of the effect on the price of some siterelated characteristics have important implications for private managers and public policy makers in the hospitality industry (Saló, et al., 2014).

The results of the paired analysis with SWOT compilation components of the strategy and indicators in the promotion strategy (Figure 4). This is in the form of a product that can affect the decision to stay in the hotel (Pristanto, Wahyuni, \& Handini, 2012). This is done because the concept and implementation of various strategies and marketing relations strategy either partially or simultaneously (Wardhana., 2013).

Based on Figure 4, the promotion strategy has various alternatives to increase the residence of Zodiak Kebon Kawung Hotel Bandung is as follows; 1) SO strategy: strategy to utilize all hotel strength that is accessibility of adequate transportation modes, modern hotel concept, foreign and domestic tourist promotion target to visit DTW Bandung; 2) Strategy ST: Strategy to improve the strength of the hotel is adequate transportation accessibility, modern hotel with low rates for tourists, foreign and domestic tourists to visit DTW Bandung will increase. Therefore, the security is required both inside and outside the Hotel; 3) WO Strategy: improving competent human resources (HR) by regular training, adding and renewing facilities and infrastructure of clean water and sewage treatment of hotel waste, seeking revamping of in-room facilities. All strategies are strategies to improve hotel room occupancy by being responsible for products and environment. This is in line with the results of the research (Han \& Yoon, 2015) which asserts that the customers are increasingly interested. Therefore, hoteliers should monitor the influence of industrial power to maintain strength, seize opportunities, avoid threats, and overcome weaknesses (Law, Tavitiyaman, \& Zhang, 2015).

\section{CONCLUSIONS}

Based on the implementation of the promotion strategy in increasing room occupancy rates at Zodiak Kebon Kawung hotels are: 1) based on internal matrix analysis factors, external matrix factor analysis summary, external matrix and cartesian diagram, it can It was found that the main strategy of the Zodiac Kebon Kawung hotel is a growth strategy where Zodiac Kebon Kawung has developed hotels, utilizing promotions need to be improved so that they have a better impact on increasing hotel room occupancy. In addition, the hotel must pay attention to and maintain the price factor by trying to be superior to competitors; 2) Based on the SWOT matrix, we can conclude strategies through internal factors, summary factors, which can be useful for progress of the Zodiac hotel in Kebon Kawung.

The results of the promotional strategies in increasing 
room occupancy at the Zodiac Kebon Kawung hotel can be used for the development of marketing management science in particular. It is recommended to analyze price variables, promotion and service quality in influencing consumer satisfaction in the strategy of increasing hotel room occupancy and discussing other factors that have not been studied in this study.

\section{REFERENCES}

Anderson, C. K. 2012. The Impact of Social Media on Lodging Performance. Cornell Hospitality Report, 12 (15), 5-14.

Brahmanto, E., Hermawan, H., \& Hamzah, F. 2017. Strategi Pengembangan Kemampuan Malayasari sebagai Daya Tarik Wisata Minat Khusus. Jurnal Media Wisata, 15(2), 588-600.

Chandra, S. M., \& Tielung, M. V. 2015. Pengaruh Kualitas Pelayanan, Promosi, Dan Lokasi Terhadap Keputusan Konsumen Menggunakan Hotel Baliem Pilamo Di Wamena. Jurnal EMBA: Jurnal Riset Ekonomi, Manajemen, Bisnis dan Akuntansi (JEMBA), 3(3), 959-970.

Etikan, I., Musa, S. A., \& Alkassim, R. S. 2016. Comparison of convenience sampling and purposive sampling. American Journal of Theoretical and Applied Statistics, 5(1), 1-4.

Gulla, R., Oroh, S. G., \& Roring, F. 2015. Analisis Harga, Promosi, dan Kualitas pelayanan terhadap Kepuasan konsumen pada hotel Manado Grace inn. Jurnal EMBA: Jurnal Riset Ekonomi, Manajemen, Bisnis dan Akuntansi, 3(1).

Han, H., \& Yoon, H. J. 2015. Hotel customers' environmentally responsible behavioral intention: Impact of key constructs on decision in green consumerism. International Journal of Hospitality Management, 45, 22-33.

Ibo A. 2018. Sektor Pariwisata Jadi Investasi Unggulan di 2018. Retrieved from https://www.liputan6.com/ lifestyle/read/3217850/sektor-pariwisata-jadiinvestasi-unggulan-di-2018

Law, V. T., Tavitiyaman, P., \& Zhang, H. Q. 2015. An analysis of industry forces, strategic implementation, and performance: Evidence from state-owned hotels in China. Journal of China Tourism Research, 11(3),
315-336.

Mandasari, K., \& SOESANTO, H. 2011. Analisis Faktor-Faktor yang mempengaruhi minat beli konsumen dalam memilih jasa perhotelan (Studi kasus pada Hotel Grasia Semarang) (Doctoral dissertation, Universitas Diponegoro).

Molina-Azorín, J. F., Tarí, J. J., Pereira-Moliner, J., López-Gamero, M. D., \& Pertusa-Ortega, E. M. 2015. The effects of quality and environmental management on competitive advantage: A mixed methods study in the hotel industry. Tourism Management, 50, 41-54.

Pristanto, Y., Wahyuni, S., \& Handini, Y. D. 2012. Analisis faktor-faktor yang mempengaruhi keputusan menginap pada hotel bintang Mulia Jember (Analys factors that influence stay overnight decision at Bintang Mulia Hotel Jember). Artikel Ilmiah Hasil Penelitian Mahasiswa, I(1), 1-6.

Radojevic, T., Stanisic, N., \& Stanic, N. 2015. Ensuring positive feedback: Factors that influence customer satisfaction in the contemporary hospitality industry. Tourism Management, 51, 13-21.

Rangkuti, F. 2011. SWOT: Balanced Scorecard. Jakarta: Gramedia Pustaka.

Saló, A., Garriga, A., Rigall-I-Torrent, R., Vila, M., \& Fluvià, M. 2014. Do implicit prices for hotels and second homes show differences in tourists' valuation for public attributes for each type of accommodation facility? International Journal of Hospitality Management, 36, 120-129.

Wardhana, A. 2013. Determinan Nilai Pelanggan dan Implikasinya pada Kinerja Pemasaran Dealer Mobil SUV Premium. TRIKONOMIKA, 12(2), 156167. Retrieved from http://journal.unpas.ac.id/ index.php/trikonomika/article/view/477.

Wijaya, C. P., Priyono, T., \& Santoso, B. 2018. Strategi Pemasaran Dalam Meningkatkan Tingkat Hunian Kamar Pada Hotel Bali Mandira Legian - Bali, 13(1), 42-53. Retrieved from http://jurnal. undhirabali.ac.id/index.php/pariwisata/article/ download/341/309

Zervas, G., Proserpio, D., \& Byers, J. W. 2017. The rise of the sharing economy: Estimating the impact of Airbnb on the hotel industry. Journal of Marketing Research, 54(5), 687-705.

Tabel 1. Budget Hotel in Bandung

\begin{tabular}{|c|c|c|c|c|c|c|c|}
\hline \multirow{2}{*}{$\begin{array}{l}\text { Rangking/ } \\
\text { Popularity }\end{array}$} & \multirow{2}{*}{ Hotel Name } & \multicolumn{5}{|c|}{ Experience from Guest } & \multirow{2}{*}{$\begin{array}{c}\text { Total } \\
\text { Review }\end{array}$} \\
\hline & & Exellent & Very Good & Avarange & Poor & Terrible & \\
\hline 1 & Ibis Budget Bandung Asia Afrika & 25 & 59 & 49 & 10 & 9 & 159 \\
\hline 2 & Hotel Citradream bandung & 26 & 63 & 36 & 4 & 0 & 129 \\
\hline 3 & Zodiak kebon Kawung & 14 & 35 & 61 & 13 & 6 & 129 \\
\hline 4 & Hotel Mutiara & 10 & 54 & 40 & 16 & 5 & 125 \\
\hline 5 & Cihampelas Hotel 2 & 31 & 20 & 36 & 11 & 12 & 109 \\
\hline
\end{tabular}


Tabel 2. Room Occupancy Rate Hotel Zodiak Kebon Kawung

\begin{tabular}{cccc}
\hline Year & Target Visitor & Number of Visitor & Presentation \\
\hline 2011 & 4000 & 3314 & $83 \%$ \\
2012 & 4000 & 3112 & $78 \%$ \\
2013 & 4000 & 3203 & $80 \%$ \\
2014 & 4000 & 2644 & $66 \%$ \\
2015 & 4000 & 2112 & $53 \%$ \\
\hline
\end{tabular}

Total Score Internal Factors Analysis Summary (IFAS)

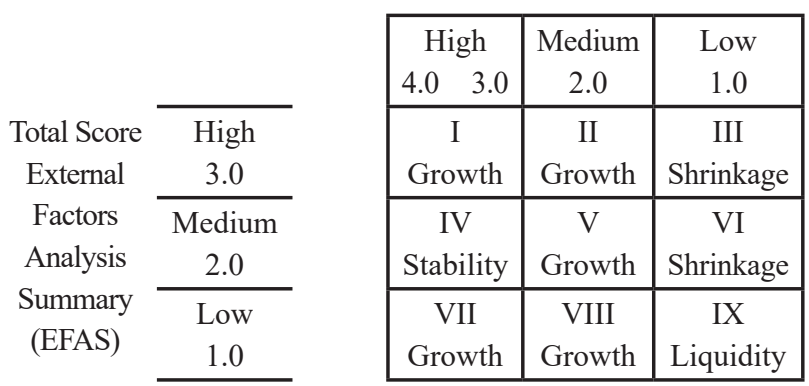

(Rangkuti, F., 2011)

Figure 1. Positioning in External Internal Matrices (IE)
Total Score Internal Factors Analysis Summary (IFAS)

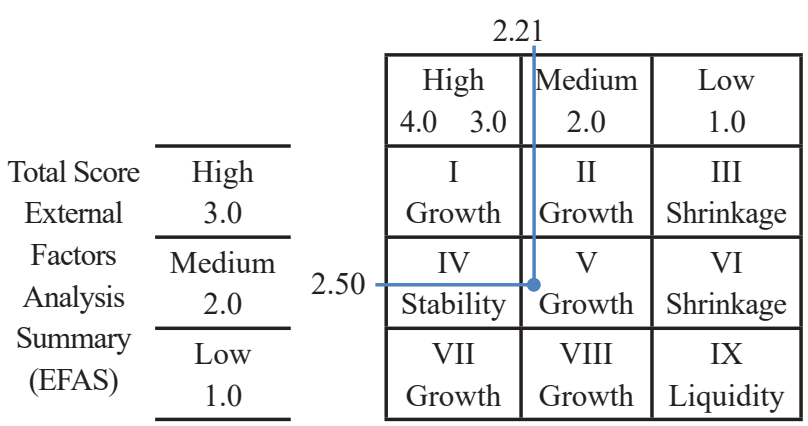

Figure 2. Positioning Results in External Internal Matrices (IE)

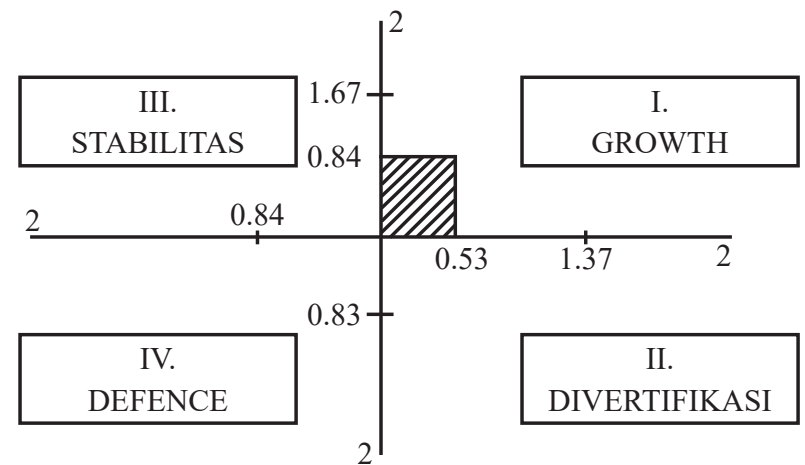

Figure 3. Cartesian Diagram

Table 3. Internal Factors Analysis Summary (IFAS)

\begin{tabular}{|c|c|c|c|c|}
\hline Internal Strategic Factors & Quality & Rating & $\begin{array}{l}\text { Bobot X } \\
\text { Rating }\end{array}$ & Comment \\
\hline \multicolumn{5}{|l|}{ Strengs } \\
\hline $\begin{array}{l}\text { Meeting Room \& Ball Room maximum } \\
200 \text { pax }\end{array}$ & 0.05 & 3 & 0.15 & Meeting rooms are flexible in concept settings \\
\hline $\begin{array}{l}\text { Access to the Airport and Railway Station } \\
\text { is easy }\end{array}$ & 0.10 & 3 & 0.30 & $\begin{array}{l}\text { The distance is approximately } 10 \text { minutes to the } \\
\text { mode of transportation }\end{array}$ \\
\hline Large parking area & 0.06 & 2 & 0.12 & Can park the bus \\
\hline Internet connection facility & 0.20 & 2 & 0.40 & Internet up to $32 \mathrm{Mbps}$ \\
\hline $\begin{array}{l}\text { The concept of a modern hotel at a bargain } \\
\text { price }\end{array}$ & 0.20 & 2 & 0.40 & Interesting young guests \\
\hline Total & 0.61 & & 1.37 & \\
\hline \multicolumn{5}{|l|}{ Weakness } \\
\hline Less competent human resources & 0.2 & 2 & 0.40 & Fluctuating service in serving guests \\
\hline The facilities have not been maintance well & 0.08 & 2 & 0.16 & $\begin{array}{l}\text { There are still some rooms that facilities less } \\
\text { well maintained }\end{array}$ \\
\hline $\begin{array}{l}\text { Do not have international promotion } \\
\text { network }\end{array}$ & 0.03 & 3 & 0.09 & $\begin{array}{l}\text { Promotion to the international area has not been } \\
\text { maximized }\end{array}$ \\
\hline $\begin{array}{l}\text { Differences of opinion between management } \\
\text { and oprasional }\end{array}$ & 0.05 & 2 & 0.10 & $\begin{array}{l}\text { Differences in the management and operational } \\
\text { mindset in the common interest }\end{array}$ \\
\hline $\begin{array}{l}\text { Organizational structure tailored to the } \\
\text { needs of budget hotels and the presence } \\
\text { of institutions that take care of innovation } \\
\text { in the field of service and product }\end{array}$ & 0.03 & 3 & 0.09 & $\begin{array}{l}\text { There is still a lack of effectiveness in the } \\
\text { organization of company employees }\end{array}$ \\
\hline Total & 0.39 & & 0.84 & \\
\hline Grand Total & 1.00 & & 2.21 & \\
\hline
\end{tabular}


Table 4. IExternal Factors Analysis Summary (EFAS)

\begin{tabular}{|c|c|c|c|c|}
\hline Exnternal Strategic Factors & Quality & Rating & $\begin{array}{l}\text { Bobot X } \\
\text { Rating }\end{array}$ & Comment \\
\hline \multicolumn{5}{|l|}{ Opportunities } \\
\hline Event in Bandung & 0.05 & 1 & 0.05 & $\begin{array}{l}\text { Foreign and domestic tourists who attend various } \\
\text { events in Bandung }\end{array}$ \\
\hline $\begin{array}{l}\text { Bandung area of cultural tourism destination, } \\
\text { culinary, nature }\end{array}$ & 0.10 & 3 & 0.30 & $\begin{array}{l}\text { Domestic and foreign tourists feel comfortable } \\
\text { with the tours as well as the culinary provided }\end{array}$ \\
\hline $\begin{array}{l}\text { The rapid economic growth of Asian and } \\
\text { Malaysian countries, Singapore, China }\end{array}$ & 0.06 & 2 & 0.12 & $\begin{array}{l}\text { With the increasing purchasing power of } \\
\text { domestic tourists, local economic growth is } \\
\text { increasing }\end{array}$ \\
\hline Hussein Sastranegara International Airport & 0.20 & 3 & 0.60 & $\begin{array}{l}\text { The airport has already opened foreign arrivals } \\
\text { gateway since } 1994\end{array}$ \\
\hline $\begin{array}{l}\text { Chinese / Chinese tendencies celebrate } \\
\text { weddings at the Hotel }\end{array}$ & 0.20 & 3 & 0.60 & Rising per capita income in Bandung \\
\hline Total & 0.61 & & 1.67 & \\
\hline \multicolumn{5}{|l|}{ Threat } \\
\hline $\begin{array}{l}\text { The establishment of new budget hotels } \\
\text { as competitors }\end{array}$ & 0.2 & 2 & 0.40 & Fluctuating service in serving guests \\
\hline Room rate competition & 0.08 & 3 & 0.24 & $\begin{array}{l}\text { Companies must think of effective ways to attract } \\
\text { consumers }\end{array}$ \\
\hline $\begin{array}{l}\text { The emergence of terrorist issues in } \\
\text { Indonesia }\end{array}$ & 0.03 & 2 & 0.06 & Adverse infrastructure and location image \\
\hline $\begin{array}{l}\text { The era of globalization by the ease of } \\
\text { foreign investment (PMA) in the field of } \\
\text { hospitality }\end{array}$ & 0.05 & 2 & 0.10 & Competitive economic growth rate \\
\hline $\begin{array}{l}\text { Tourist destinations in Thai, Filiphine } \\
\text { countries are cheaper, lower and smoother } \\
\text { so it is easy to reach than DTW Bandung }\end{array}$ & 0.03 & 1 & 0.03 & Lack of international media promotion \\
\hline Total & 0.39 & & 0.83 & \\
\hline Grand Total & 1.00 & & 2.50 & \\
\hline
\end{tabular}




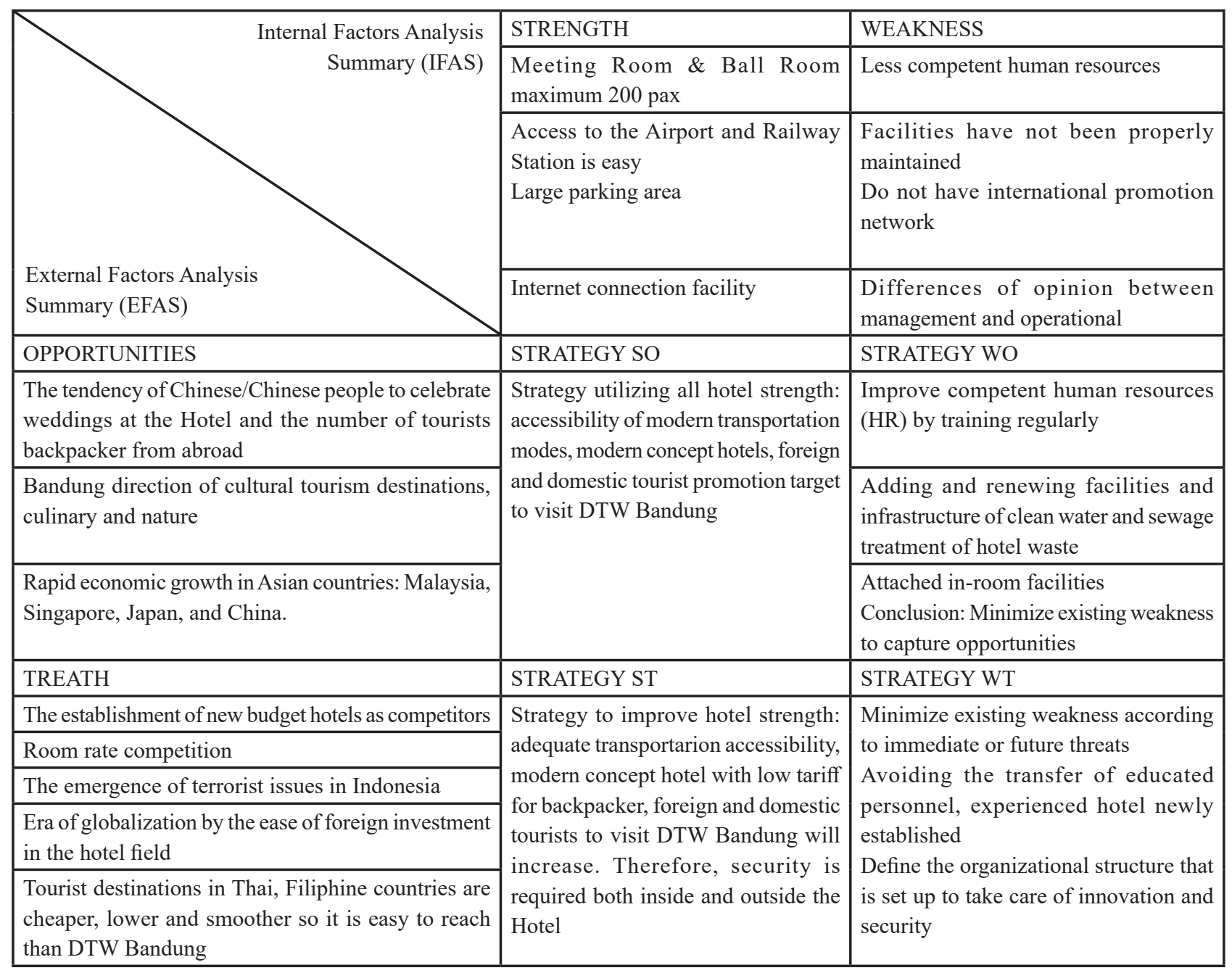

Fugure 4. Matriks SWOT Hotel Zodiak Kebon Kawung 